\title{
Main priorities of state investment and innovation policy of the republic of Uzbekistan
}

\section{Abror KABULOV ${ }^{1}$ Feruza SIDIKOVA ${ }^{2}$}

\section{Plekhanov Russian University of Economics in Tashkent}

\begin{tabular}{l} 
ARTICLE INFO \\
\hline Article history: \\
Received September 2020 \\
Received in revised form 15 \\
September 2020 \\
Accepted 25 September \\
2020 \\
Available online \\
1 October 2020
\end{tabular}

\section{Keywords:}

Ensuring

Security

Information security

Mass media

Media security.

\begin{abstract}
The investment and innovation policy followed by the state has a huge impact on development of investment in the country, both private and public level. It forms so-called innovative and investment climate in the country. Therefore, the article discusses some of the ways of development and innovation and investment policy in the Republic of Uzbekistan at present.
\end{abstract}

\section{1-1415/C) 2020 in Science LLC.}

This is an open access article under the Attribution 4.0 International (CC BY 4.0) license (https://creativecommons.org/licenses/by/4.0/deed.ru)

\section{Основные приоритеты государственной инвестиционной и инновационной политики Республики Узбекистан}

\section{Ключевые слова:}

Технологии

Глобализация

Научно-технический

прогресс

Цифровая экономика

\section{АННОТАЦИЯ}

Инвестиционная и инновационная политика, которой придерживается государство, имеет огромное влияние на развитие капиталовложений в стране, как частных, так и государственных. Именно она формирует так называемый инновационно-инвестиционный климат страны. Поэтому в статье рассмотрены некоторые пути развития инновационно-инвестиционный политики в настоящее время в Республике Узбекистан.

\footnotetext{
${ }^{1} \mathrm{PhD}$, Associate Professor, Dean of Economy and Business Faculty, Plekhanov Russian University of Economics in Tashkent

E-mail: kabulov51@mail.ru

${ }^{2}$ Senior Lecturer, Dean of Digital Economy and Finance Faculty, Plekhanov Russian university of Economics in Tashkent, Tashkent, Uzbekistan E-mail: feruzik2003@yandex.ru
} 
Uzbekistan needs to build not an import-substituting, but an innovative and investment economy in order to break into world markets.

The development of innovation-oriented industries seems to be not only economic task, but also a political one. In the era of globalization of the world economy the course towards innovation for countries with large population such as Uzbekistan has no alternative.

An innovation-investment economy is also necessary in itself because it creates a new cultural environment. At the same time, it is obvious that an innovative economy requires a certain environment for development. A business climate in Uzbekistan is not yet fully conducive to emergence of company that engages in commercialization of scientific developments. full-fledged science, education, serious institutional changes are needed, which will allow mobilizing human resources to function such project.

It should be also noted that in Uzbekistan there is a certain gap between the potential of fundamental scientific developments and their implementation in innovative technologies of production and everyday life, in technology and consumer goods.

This gap is generated by weakness of subsequent stages of development of scientific and technological progress, lack of proper motivation of Uzbek entrepreneurs to master technological innovations in the conditions of low wages, monopoly and insufficient development of competition. Under these conditions, restructuring cannot get the proper development in industries with high share of added value.

A share of intellectual products in GDP of the country remains very low. In these conditions, the issue under research is becoming especially relevant in the light of established strategic goal of transferring Uzbekistan to innovation and investment path of development [1].

There is an urgent need for new market mechanisms for regulating the innovation climate, mechanisms under which it is profitable to invest in high technologies. The state should initiate innovative activities. The most important direction of strategic development should be creation of innovative infrastructure that will become an intermediary between science and business and will include a whole range of links that provide conditions for innovative development. These are techno parks, technology centers, specialized financial structures, investment (venture) funds and consulting groups.

The innovation and investment path of development of economy of Uzbekistan in the conditions of development of digital economy should allow using fully competitive advantages and compensating competitive disadvantages, in particular, transport and resource constraints, minimizing their negative effect as much as possible [4].

In this regard, innovative industries products differ from conventional products and are ideal for export due to their specificity. This type of product, first of all, is characterized by science intensity, energy and resource saving, simplicity and low cost of transportation, which is extremely important for Uzbekistan in the conditions of existing transport, energy and raw material constraints.

For the development of innovation and investment economy of Uzbekistan, its competitive advantages have a great importance, which include the widespread use of higher education, rather liberal legislation on capital flow. However, the most important competitive advantage of Uzbekistan is relatively low cost of skilled labor according to Western standards, which affects final price of the product. 
It should be noted that today the most dynamically developing segment of innovation and investment sector of the Republic of Uzbekistan is information technologies [5].

In the condition of implementation of tasks outlined in Action Strategy for Economic Development of the Republic of Uzbekistan, the issues of introducing advanced information and communication technologies as well as innovative technologies acquire special significance.

Thus, the President of Uzbekistan Shavkat Mirziyoyev held a meeting in Tashkent on September 19, 2018 to analyze the work being done in information technologies and communications system, to identify additional measures for accelerated development of this area. "Information technologies and communications contribute to accelerated development of all spheres, create convenience for people. The tasks for the development of this sphere, set at the beginning of the year, have not been fully fulfilled. A state of attracting investments in the industry, export of services and finished software products is completely unsatisfactory" said Shavkat Mirziyoyev [3].

A state has been tasked with bringing the investments volume, especially direct ones, in the development of information technologies to \$500 million in 2020.

Successful implementation of large-scale reforms at current stage of country development and achievement of the goals of Action Strategy in five priority areas of the development of the Republic of Uzbekistan in 2017-2021 require creation of completely new and efficiently functioning system of public administration, organization of coordinated activities of government bodies and executive authorities [2].

Potential of innovation and investment development of Uzbekistan is also evidenced by index of its innovation and investment potential, which is one of components of compiling global report on competitiveness of the countries of the world. In terms of this index, Uzbekistan is ahead of such countries as Georgia, Egypt, Kyrgyzstan, Moldova, Serbia, although insufficient innovation and investment potential of the country should still be recognized.

All this testifies to great potential of information technologies sector and related services in Uzbekistan and that this sector, in particular, telecommunications services sector, can become a key source of institutional and high-quality innovation and investment transformation and further development of economy of Uzbekistan.

At the same time, taking into account the difficulties associated pandemic situation, it is nevertheless necessary to attract significant investments for the development of this industry, which is a rather serious problem not only for economy of Uzbekistan, but also for entire world economy.

Financial system of Uzbekistan as a whole and its individual segments, including banking one are still not full-fledged and effective institutions of financial intermediation. There are many reasons for this circumstance, many of which are institutional in nature, including:

- insufficiently perfect legislation regulating this area;

- absence of approved comprehensive programs and incentives of strategical development of financial sector;

- unfavorable tax policy and significant size of shadow economy;

- imperfection of institutions of corporate governance, protection of property rights and contractual relations; 
- ineffectiveness of judicial and legal levers aimed at reforming them.

As for foreign direct investment (FDI), their volumes are also clearly insufficient for significant impact on economy of the country. They have not recently exceeded $10 \%$ of GDP. Small volumes of FDI are primarily associated with some problems of investment climate in Uzbekistan. According to various international organizations, main factors of unfavorable investment climate in Uzbekistan are tax administration and rates, macroeconomic instability (country risks), customs relations, obstacles to land availability and licensing, etc.

At the same time, a particular important is the fact that venture capital funds traditionally invest in business related to modern science-intensive and information technologies in such industries as electronics, computer and information technologies and systems, software, biotechnology, etc. in innovative industries.

Venture capital has contributed to success of companies such as Microsoft, Intel, Apple Computer, Lotus, etc. Creation and implementation of venture financing mechanisms can be an important step in the development of economy of Uzbekistan, since through venture financing it is becoming possible to solve simultaneously several strategic tasks.

First, venture capital financing provides an opportunity to develop innovative industries, in particular, information technologies, which will help to solve several macroeconomic problems, including increase in exports and improvement in balance of payments, which will ultimately lead to improvement in qualitative characteristics of economic growth.

Secondly, the results of using this model will be development of capital market as a whole, as well as emergence and development of other institutional investors. Venture funds can raise capital from different insurance and investment companies, etc.

Thirdly, venture capital financing will contribute to establishment and improvement of corporate management. Indeed, for the countries with economies in transition, improving corporate governance is an important aspect of transition to market economy, which can lead to creation of trust and interest from the part of investors and, more generally, can significantly improve the prospects for sustainable economic growth of the country.

It is necessary to note that, despite revival of transformations in innovation economy of Uzbekistan in recent years, they have not yet yielded real results.

Today, new knowledge is not funded by the state, and instead of national investors it is done by Western countries based on scientific research, the results of which are appropriated.

It is also important to take into account the mechanisms of national innovation and investment development used in foreign developing countries.

Recently, particular importance for the development of the national economy has been given to the development of tourism, which has become the main direction of state policy.

A key task is to promote tourism product of Uzbekistan in the world market of tourism services by forming an idea of Uzbekistan as a country which is attractive and favorable for tourism, as well as integration of national tourism market into the world in order to ensure a stable increase in a number of international tourists. 
In recent years, the country has also formed a detailed information database in tourism sector of the Republic of Uzbekistan. In the condition of implementation of marketing policy of tourism product of the Republic of Uzbekistan, it is presented and positioned at international tourism exhibitions and fairs, which is especially significant for stable increase in a number of international tourist arrivals to Uzbekistan.

A number of tourists visiting Uzbekistan is constantly growing. In this regard, the authors estimate a potential of foreign investment in tourism industry as realized at the level below average.

An important task in the development of tourism in Uzbekistan is some problems in purposeful and forward-looking investment policy. A state should try to coordinate the activity of investors interested in making investments in tourism. Investment in tourism should be long-term, as the first period makes little profit. The state should act as a guarantor for depositors.

Among the problems in the sphere of tourism, it should be noted the lack of entertainment centers outside capital, high cost of air travel, and disadvantages in general level of hotel service are noticeable.

In order to reach current level of tourism development, it is necessary to carry out a great work in all spheres of economy and in many other areas. The existing problems in republic are numerous and varied that, in fact, it is impossible to find a fruitful solution without integrated approach.

Foundations for tourism development and transformation of Uzbekistan into attractive country have already been laid in Uzbekistan. And honest, fair competition only stimulates the development of the most important service market in the republic.

An investment project for construction of nuclear power plant in Uzbekistan near Lake Tudakul, located on the border with Navoi and Bukhara regions, is gaining considerable importance. This will be another impetus for close investment cooperation between Uzbekistan and the Russian Federation.

Thus, in the conditions of modern globalization, a priority importance is acquiring not only attraction of foreign investment, but also assess the feasibility, rationality and effectiveness of their use. Consequently, the definition of effectiveness of foreign investments gives an answer to the question of expediency of their attraction and use.

\section{References:}

1. Address of the President of the Republic of Uzbekistan Shavkat Mirziyoyev to Oliy Majlis. Newspaper "Narodnoye Slovo" of January 24, 2020 URL : https : // nrm . uz / contentf ?doc $=409961$

2. Decree of the President of the Republic of Uzbekistan. Action Strategy for five priority directions of development of the Republic of Uzbekistan in 2017-2021. Newspaper "Narodnoe Slovo" No. 28 (6692) of February 8, 2017 UR: http: // www. press-service.uz/ $\mathrm{ru} /$ document / 5482 /

3. Meeting with the participation of the President of the Republic of Uzbekistan. September 19, 2018, Tashkent.

4. Abdurakhmanov K.Kh. "Digital Uzbekistan - 2030 will lead out of the laggards". Newspaper "Narodnoye Slovo" No. 74 (7545) of April 10, 2020

5. Digital economy: features and development trends / Access mode: http://investin.com/About/Economy. 


\section{Библиографические ссылки}

1. Послание Президента Республики Узбекистан ШавкатаМирзиеева Олий Мажлису. Газета «Народное слово» от 24 января 2020 г. URL: https://nrm.uz/contentf?doc $=409961$

2. Указ Президента Республики Узбекистан. Стратегия действий по пяти приоритетным направлениям развития Республики Узбекистан в 2017-2021 годах. Газета «Народное слово» №28 (6692) от 8 февраля 2017 г. URL: http://www. pressservice.uz/ru/document/5482/

3. Совещание с участием Президента Республики Узбекистан. 19 сентября 2018 года, г. Ташкент.

4. Абдурахманов К.Х. «Цифровой Узбекистан - 2030» выведет из отстающих. Газета «Народное слово» №74 (7545) от 10 апреля 2020 г.

5. Цифровая экономика: особенности и тенденции развития / Режим доступа: http://investin.com/About/Economy. 